\section{International Journal \\ of \\ English Studies}

\section{IJES}

http://revistas.um.es/ijes

\title{
Foreign language classroom anxiety among English for Specific Purposes (ESP) students
}

\author{
MARIAN AMENGUAL-PIZARRO* \\ Universitat de les Illes Balears (Spain)
}

Received: 02/03/2017. Accepted: 05/10/2018.

\begin{abstract}
This study aims at exploring the degree of Foreign Language Anxiety (FLA) towards the learning of English that English for Specific Purposes students report experiencing. The participants in this study were 67 undergraduates at the University of the Balearic Islands enrolled in two university degree programs. The Foreign Language Classroom Anxiety Scale (FLCAS) (Horwitz, Howitz \& Cope, 1986) was used to collect data. The findings reveal that most students suffered from average to high anxiety levels. Communication apprehension was found to be the main source of participants' FLA followed by fear of negative evaluation and test anxiety. The data also showed statistically significant differences across students' university degree programs related to test anxiety and fear of negative evaluation. No statistically significant gender differences in FLA levels were observed. Finally, correlation analyses revealed significant negative associations between participants' self-perceived English proficiency and their FLA levels associated with listening and speaking skills.
\end{abstract}

KEYWORDS: ESP students, Foreign Language Anxiety, foreign language learning.

\section{INTRODUCTION}

Affective variables have long been recognised to play a crucial role in the process of learning a second language (L2). Over the last decades, emotional aspects such as Foreign Language

*Address for correspondence: Marian Amengual-Pizarro. Universitat de les Illes Balears, Spain; e-mail: marian.amengual@uib.es 
Anxiety (FLA) have been the focus of much debate. Specifically, this affective factor is thought to be a major obstacle to learning and production of the target language) (Horwitz, 2001; Krashen, 1985; Pavlenko, 2011; Phillips, 1992), regardless of the language teaching methodology (see Liu, 2013). Horwitz et al. (1986: 128) defined FLA as "a distinct complex construct of self-perceptions, beliefs, feelings, and behaviours related to classroom language learning arising from the uniqueness of language learning process". Those authors highlight the distinctive feature of FLA as a situation-specific type of anxiety associated with L2 learning contexts. MacIntyre (1999: 27) described FLA as the "worry and negative emotional reaction aroused when learning or using a second language". This emotional state may interfere with production of the new language causing apprehension, nervousness, worry, and tension related to L2 learning (MacIntyre \& Gardner, 1994, 1991). Thus, many research studies provide evidence of a significant negative correlation between FLA and L2 achievement) (Horwitz, 2001; Onwuegbuzie, Bailey \& Daley, 2000; Williams \& Andrade, 2008). According to researchers, foreign language classroom situations are especially anxiety-provoking contexts due to their interactive nature (Yang, 2012). In fact, although FLA has been linked to different language skills, oral production is viewed as the greatest source of anxiety in the L2 classroom mainly due to students' fears to communicate publicly by means of a language they do not master completely (Aida, 1994; Choi, 2016; Horwitz et al., 1986; MacIntyre \& Gardner, 1991; Mak, 2011; Matsuda \& Gobel, 2004; Park, 2014; Woodrow, 2006; Young, 1992). According to Pellegrino (2005: 7), "to learn another language is to redefine yourself publicly, socially, and personally." In the same vein, some authors point out that the difficulties experienced at trying to express themselves in the L2 may challenge students' self-concept and identity as competent speakers, which can easily result in worry and frustration (Ortega-Cebreros, 2003; Schumann, 1978).

Thus, although some studies have suggested that FLA may have a positive effect on language learning, drawing a distinction between beneficial/ facilitating vs. inhibitory/ debilitating anxiety (Bailey, 1995; Dörnyei, 2005; Spielman \& Radnofsky, 2001), most researchers report the detrimental or debilitating effects of FLA (Cheng, Horwitz \& Shallert, 1999; Horwitz, 2001). These latter effects can manifest in many different ways such as avoidance behaviour (e.g. arriving late, avoiding participating in the classroom or interacting, skipping classes), face-saving (e.g. joking) or minor physical symptoms (e.g. sweating, headaches, etc.) (see Gregersen, 2007; Horwitz \& Young, 1991). FLA is, therefore, believed to hinder learning and affect the efficiency of language learning (Onwuegbuzie et al., 2000).

Horwitz et al., (1986) designed the Foreign Language Classroom Anxiety Scale (FLCAS) to measure the level of anxiety of L2 learners while learning the target language in the context of the classroom. The FLCAS has been extensively used in language anxiety studies across different disciplines (i.e. psychology, education, applied linguistics, etc.) due to its high reliability and validity (see Aida, 1994; Arnaiz \& Guillén, 2012, 2013; Choi, 2016; 
Kruk, 2018; Mak, 2011; Park, 2014; Park \& French, 2013; Rodríguez \& Abreu, 2003). The scale deals with general foreign language anxiety although it especially highlights speaking and listening skills. According to these authors, FLA can be associated with three main interrelated types of anxiety: communication apprehension, test anxiety and fear of negative evaluation. Communication apprehension is described as fear about communication with people or in front of others. Apparently, the lack of proficiency in the L2 can lead to anxiety, frustration and self-consciousness in some learners. Test anxiety refers to fear of failure or failing in tests. Test-anxious students tend to feel constantly evaluated and are usually afraid of making mistakes. Finally, fear of negative evaluation is related to learners' worry about peoples' negative judgement or evaluations. In order to reduce the possibility of obtaining negative evaluations from their teachers or classmates, anxious students may avoid interacting in the L2, which prevents them from improving and developing their oral communication skills in the L2 (Arnaiz \& Guillén, 2012; Gregersen, 2007). Therefore, these three main interrelated factors negatively affect the learning of the L2 (Horwitz et al., 1986).

Since in today's globalised university context Spanish university students are currently required to demonstrate an intermediate level of English (B1 or B2) according to the CEFR (Common European Framework of Reference for Languages) prior to graduation (Amengual, 2017), the investigation of English for Specific Purposes (ESP) students' affective factors involved in learning English as a foreign language is thought to be of particular relevance. Furthermore, to the best of our knowledge, few empirical studies have investigated FLA in a Spanish university context (see Arnaiz-Castro \& Guillén, 2013; 2012). Therefore, this study attempts to fill this gap in the existing literature by exploring the influence FLA may have on the language learning process of Spanish ESP students.

\section{RESEARCH QUESTIONS}

The main purpose of this study is to examine the role of FLA that ESP students, taking English lessons as a degree requirement, report experiencing. More specifically, the study addressed the following research questions:

(1) What level of FLA do ESP students have towards the learning of English?

(2) What is the main source of FLA among ESP students?

(3) Are there any differences in the degree of FLA that ESP students experience across university degree programs?

(4) Are there any differences in the degree of FLA that ESP students experience across gender?

(5) What is the correlation between foreign language anxiety levels and students' perceptions of their own proficiency? 


\section{METHOD}

\subsection{Participants}

The participants in this study were third and fourth-year ESP students at the University of the Balearic Islands (UIB). A total of 67 students were enrolled in two ESP university degree courses: 'English for Philology' $(\mathrm{T}=34)$ and 'English for Biology' $(\mathrm{T}=32)$, designed to help them meet the mandatory requirement for all undergraduates to demonstrate a B2 (CEFR) level of English proficiency before graduation.

As regards gender, $59.7 \%$ were female and $40.3 \%$ were male. The majority of respondents $(89.6 \%)$ were between 20 and 25 years of age, $7.5 \%$ of the participants were between 26 and 35 years, and only $3 \%$ of them were between 36 and 45 years old.

\subsection{Instrument and data collection}

A closed questionnaire was administered to all participants in mid-October 2017. The questionnaire consisted of three sections. The first section intended to collect background information about participants (age, sex, etc.). The second section included the Spanish version of the Foreign Language Classroom Anxiety Scale (FLCAS) (see Pérez-Paredes \& Martínez-Sánchez, 2001) developed by Horwitz et al., (1986). The FLCAS is a widely recognised instrument to assess general foreign language anxiety. It consists of 33 items which are rated on a 5-point Likert scale ranging from 1 ('strongly agree') to 5 ('strongly disagree'). The FLCAS aims to assess three types of performance anxieties associated with foreign language anxiety: communication apprehension (items 1, 4, 9, 14, 15, 18, 24, 27, 29, 30 and 32), test anxiety (items 3, 5, 6, 8, 10, 11, 12, 16, 17, 20, 21, 22, 25, 26 and 28) and fear of negative evaluation (items 2, 7, 13, 19, 23, 31 and 33). An anxiety score is derived for each respondent by adding up his or her ratings on the thirty-three items. Total scores of the scale range from 33 to 165 . Reverse values were assigned to a total of 9 items $(2,5,8,11,14$, 18, 22, 28 and 32) so, in all instances, a low score represents a high degree of anxiety. The third section of the questionnaire asked participants to provide self-ratings of their proficiency in English in the four language skills (i.e. writing, reading, speaking and listening) on a 5-point Likert scale ranging from 1 (excellent) to 5 (very poor).

Participants were asked to complete the questionnaire during a regular class period time for about 30 minutes. The test administrator stayed in the classroom in order to solve any possible doubts from students, and collected the questionnaires after completion. The quantitative results were analysed with the Statistical Package for the Social Sciences (SPSS) 22.0. Similar to the internal reliability measure obtained by Horwitz et al., (1986) in their study $(\alpha=.93)$, the Cronbach's alpha coefficient of the scale in this study was .937 , which indicates a high level of internal consistency with this specific sample (67 respondents). 


\section{RESULTS AND DISCUSSION}

\subsection{What level of FLA do ESP students have towards the learning of English?}

In order to know participants' general level of language classroom anxiety, each respondent's total scores were calculated. The actual range of scores in this study was from 48 (extremely anxious) to 145 (not at all anxious) (97). Following Arnaiz and Guillén (2012), participants were classified into three groups according to the level of anxiety they exhibited. Thus, students scoring between 48 and 80 were identified as students with high anxiety, those scoring between 81 and 113 were identified as students with average anxiety levels, and those scoring between 114 and 145 were classified as students with low anxiety. Descriptive statistics indicate that the majority of students in the study were students with average anxiety levels (44.3\%). A total of $26.6 \%$ were identified as students with high anxiety and $31.1 \%$ were classified as students with low anxiety. Therefore, $71.9 \%$ of the respondents seemed to experience average to high anxiety levels. The mean language anxiety value for the 67 participants was 97.92 and the standard deviation (SD) was 23.63.

\subsection{What is the main source of FLA among ESP students?}

The mean scores and standard deviations were analysed for the three types of performance anxieties associated with FLA (communicative apprehension, test anxiety and fear of negative evaluation). The data have been arranged in ascending order of importance to facilitate comprehension. The lowest scores obtained by the instrument indicate in all instances a higher level of FLA.

Table 1 shows participants results on communicative apprehension. As can be observed, the three top highest anxiety-provoking factors reported by participants are clearly related to speaking anxiety: 'I start to panic when I have to speak without preparation in language class' (item 9, $\bar{x}=2.42$ ), 'I never feel quite sure of myself when I am speaking in my foreign language class' (item $1, \overline{\mathrm{x}}=2.45$ ) and 'I get nervous and confused when I am speaking in my language class' (item $27, \bar{x}=2.64$ ). The first two items within this category registered a mean score below 2.5 points on a 5-point scale, which indicates a considerable level of FLA. In light with previous research studies (Aida, 1994; MacIntyre \& Gardner, 1994, 1991; Yang, 2012), these results confirm that ESP students seem to feel uncomfortable and self-conscious when they have to use the L2 in class, which can easily result in apprehension and anxiety for most of them.

As regards the three lowest scoring anxiety items, the data reveal the following: 'I would not be nervous speaking the foreign language with native speakers' (item $14^{*}, \overline{\mathrm{x}}=$ 3.03), 'I feel overwhelmed by the number of rules you have to learn to speak a foreign language (item 30, $\overline{\mathrm{x}}=3.26$ ), and finally 'I would probably feel comfortable around native 
speakers of the foreign language' (item $32 *, \overline{\mathrm{x}}=3.40$ ), which is believed to be the least anxiety-provoking factor in terms of communication apprehension. Thus, ESP students are found to feel less nervous and very much more comfortable speaking, and being around foreign native language speakers (item 14, and item 32), than speaking in the context of the classroom. This finding is congruent with the situation-specific characterization of FLA advocated by Horwitz et al., (1986).

\begin{tabular}{|c|c|c|c|}
\hline Items: Communication apprehension & $\mathbf{N}$ & Mean & SD \\
\hline $\begin{array}{l}\text { 9. I start to panic when I have to speak without preparation in } \\
\text { language class. }\end{array}$ & 67 & 2.42 & 1.220 \\
\hline $\begin{array}{l}\text { 1. I never feel quite sure of myself when I am speaking in my } \\
\text { foreign language class. }\end{array}$ & 67 & 2.45 & 1.210 \\
\hline $\begin{array}{l}\text { 27. I get nervous and confused when I am speaking in my language } \\
\text { class. }\end{array}$ & 67 & 2.64 & 1.240 \\
\hline $\begin{array}{l}\text { 15. I get upset when I don't understand what the teacher is } \\
\text { correcting. }\end{array}$ & 67 & 2.66 & 1.355 \\
\hline $18 *$. I feel confident when I speak in foreign language class. & 67 & 2.70 & 1.404 \\
\hline $\begin{array}{l}\text { 29. I get nervous when I don't understand every word the language } \\
\text { teacher says. }\end{array}$ & 67 & 2.92 & 1.281 \\
\hline $\begin{array}{l}\text { 24. I feel very self-conscious about speaking the foreign language } \\
\text { in front of other students. }\end{array}$ & 67 & 2.96 & 1.308 \\
\hline $\begin{array}{l}\text { 4. It frightens me when I don't understand what the teacher is } \\
\text { saying in the foreign language. }\end{array}$ & 67 & 2.97 & 1.392 \\
\hline $\begin{array}{l}14 * \text { I would not be nervous speaking the foreign language with } \\
\text { native speakers. }\end{array}$ & 67 & 3.03 & 1.348 \\
\hline $\begin{array}{l}\text { 30. I feel overwhelmed by the number of rules you have to learn to } \\
\text { speak a foreign language. }\end{array}$ & 67 & 3.26 & 1.207 \\
\hline $\begin{array}{l}32 * \text {. I would probably feel comfortable around native speakers of } \\
\text { the foreign language. }\end{array}$ & 67 & 3.40 & 1.382 \\
\hline
\end{tabular}

*Reversed values: The lowest scores represent at all times a high anxiety level.

Table 1. Participants' level of communication apprehension.

The overall mean of communication apprehension was the lowest $(\bar{x}=2.84)$ of the three types of performance anxieties associated with FLCA, which indicates that this factor is the most anxiety-provoking for ESP students.

As far as test anxiety is concerned, as can be observed (Table 2), the three most anxiety-inducing factors related to this type of performance anxiety were the following: 'I worry about the consequences of failing my foreign language class' (item $10, \bar{x}=2.04$ ), 'I feel more tense and nervous in my language class than in my other classes' (item $26, \bar{x}=$ 2.53 ), and 'In language class, I can get so nervous I forget things I know' (item 12, $\bar{x}=$ 2.64). These findings show that most students do not feel at ease in their language classrooms and that they are especially concerned about the consequences of failing the course subject. In fact, this latter aspect exhibited the most critical level of classroom anxiety associated with FLCA across the three main performance anxiety subtypes (Salehi \& Marefat, 2014). This is clearly linked to the pressure ESP students experience due to the need to pass the language 
course in order to fulfil the compulsory requirement to demonstrate a B2 level (CEFR) of English proficiency before graduation (see Arnaiz \& Guillén, 2013).

\begin{tabular}{|c|c|c|c|}
\hline Items: Test anxiety & $\mathbf{N}$ & Mean & SD \\
\hline $\begin{array}{l}\text { 10. I worry about the consequences of failing my foreign language } \\
\text { class. }\end{array}$ & 67 & 2.04 & 1.364 \\
\hline $\begin{array}{l}\text { 26. I feel more tense and nervous in my language class than in my } \\
\text { other classes. }\end{array}$ & 67 & 2.53 & 1.361 \\
\hline 12. In language class, I can get so nervous I forget things I know. & 67 & 2.64 & 1.322 \\
\hline $\begin{array}{l}\text { 3. I tremble when I know that I'm going to be called on in language } \\
\text { class. }\end{array}$ & 67 & 2.85 & 1.361 \\
\hline $\begin{array}{l}\text { 6. During language class, I find myself thinking about things that } \\
\text { have nothing to do with the course }\end{array}$ & 67 & 2.85 & 1.280 \\
\hline $\begin{array}{l}\text { 20. I can feel my heart pounding when I'm going to be called on in } \\
\text { language class. }\end{array}$ & 67 & 2.87 & 1.313 \\
\hline 17. I often feel like not going to my language class. & 67 & 3.03 & 1.141 \\
\hline $\begin{array}{l}11^{*} \text {. I don't understand why some people get so upset over foreign } \\
\text { language classes }\end{array}$ & 67 & 3.04 & 1.160 \\
\hline $22^{*}$. I don't feel pressure to prepare very well for language class. & 67 & 3.04 & 1.147 \\
\hline $8^{*}$. I am usually at ease during tests in my language class. & 67 & 3.12 & 1.066 \\
\hline $\begin{array}{l}\text { 16. Even if I am well prepared for language class, I feel anxious } \\
\text { about it. }\end{array}$ & 67 & 3.13 & 1.336 \\
\hline $\begin{array}{l}\text { 25. Language class moves so quickly I worry about getting left } \\
\text { behind. }\end{array}$ & 67 & 3.30 & 1.163 \\
\hline $\begin{array}{l}28 * \text { When I am on my way to language class, I feel very sure and } \\
\text { relaxed }\end{array}$ & 67 & 3.37 & 1.369 \\
\hline $\begin{array}{l}5^{*} \text { It wouldn't bother me at all to take more foreign language } \\
\text { classes. }\end{array}$ & 67 & 3.94 & 1.336 \\
\hline $\begin{array}{l}\text { 21. The more I study for a language test, the more confused I get. } \\
\text { Overall mean }=\mathbf{3 . 0 4}\end{array}$ & 67 & 4.21 & 0.826 \\
\hline
\end{tabular}

*Reversed values: The lowest scores represent at all times a high anxiety level.

Table 2. Participants' level of test anxiety.

The least anxiety-provoking factors related to test anxiety were the following: "When I am on my way to language class, I feel very sure and relaxed' (item $28^{*}, \overline{\mathrm{x}}=3.37$ ), followed next in order by 'It wouldn't bother me at all to take more foreign language classes' (item $5^{*}, \quad \bar{x}=3.94$ ) and 'The more I study for a language test, the more confused I get' (item $21, \overline{\mathrm{x}}=4.21$ ), which was ranked last in order of importance. As can be observed, the high scores registered in these items indicate that students do not feel highly anxious about attending their English lessons (item 28) and, in fact, they do not seem to exclude the possibility of taking additional English lessons in the future (item 5). They also believe that studying the subject helps them improve and clarify ideas (item 21). In fact, it is worth mentioning that all the items related to test anxiety except for item 10 registered mean scores above 2.5 points on a 5-point scale. Furthermore, 9 out of 15 items scored above 3 points on the scale, which indicates that students do not generally seem to experience a high degree of anxiety during tests in their language class, although, admittedly, they reported feeling very anxious about the possibility of failing the subject (item 10), since this could prevent them from graduating. The overall mean score of test anxiety was the highest of the three subtypes 
of performance anxiety associated with overall FLCA $(\overline{\mathrm{x}}=3.04)$. This indicates that this type of anxiety seems to have the least negative effect on ESP students.

As regards fear of negative evaluation (Table 3), respondents admitted getting very nervous when the language teacher asked them questions that they had not prepared in advance (item 33, $\bar{x}=2.48$ ) (Choi, 2016; Mak, 2011). In fact, this was the lowest scoring item within this category with a mean value below 2.5 on a 5 -point scale, which means it was a highly anxious-provoking aspect. It was followed by students' reticence to volunteer answers in the language class due to embarrassment or loss of face (item 13, $\bar{x}=2.55$ ), and by students' worry about making mistakes (item $2, \bar{x}=2.63$ ). These aspects clearly point to participants' concern about the academic and personal evaluation of their performance in the L2 in front of their classmates. As some authors explain, this excessive worry about the impression they may transmit can constitute an obstacle to taking risks and engaging in activities that might help them improve their language skills (Arnaiz \& Guillén, 2012; Gregersen, 2007; Kim, 2009). In spite of this, when comparing themselves with other students, participants do not necessarily believe that the other students in class are better at languages than they are (item $7, \bar{x}=2.82$ ). Likewise, they are not afraid that their fellow classmates will laugh at them when they speak the L2 (item 31, $\bar{x}=3.51$ ). These two latter aspects might be attributable to the homogeneity of the English level of the participants, since undergraduates in possession of a certified B2 English level do not need to attend these language courses. Finally, participants show little concern about being corrected by the language teacher (item 19, $\bar{x}=3.65$ ). The overall mean score of fear of negative evaluation $(\bar{x}=2.92)$ indicates that this type of performance anxiety was considered to be the second source of participants' FLCA after communication apprehension.

\subsection{Are there any differences in the degree of FLA that ESP students experience across university degree programs?}

In order to investigate the third research question, a series of independent samples t-tests were conducted to examine whether there was a significant relationship between FLA and students' university degree. The descriptive statistics indicate that, overall, philology students experience a lower level of FLA than biology students in all items associated with communication apprehension except for item 15: 'I get upset when I don't understand what the teacher is correcting' ( $\bar{x}=2.50$ vs. $\bar{x}=2.82$ ), item 27: 'I get nervous and confused when I am speaking in my language class' $(\bar{x}=2.62$ vs. $\bar{x}=2.67)$, and item 30 : 'I feel overwhelmed by the number of rules you have to learn to speak a foreign language ( $\bar{x}=$ 3.24 vs. $\bar{x}=3.28$ ). However, the data did not reveal statistically significant differences across university degree programs in terms of communication apprehension. 


\begin{tabular}{|c|c|c|c|}
\hline Items: Fear of negative evaluation & $\mathbf{N}$ & Mean & SD \\
\hline $\begin{array}{l}\text { 33. I get nervous when the language teacher asks questions which I } \\
\text { haven't prepared in advance. }\end{array}$ & 67 & 2.48 & 1.153 \\
\hline 13. It embarrasses me to volunteer answers in my language class. & 67 & 2.55 & 1.385 \\
\hline 2*I don’t worry about making mistakes in language class. & 67 & 2.63 & 1.265 \\
\hline $\begin{array}{l}\text { 23. I always feel that the other students speak the foreign language } \\
\text { better than I do. }\end{array}$ & 67 & 2.75 & 1.159 \\
\hline $\begin{array}{l}\text { 7. I keep thinking that the other students are better at languages } \\
\text { than I am. }\end{array}$ & 67 & 2.82 & 1.290 \\
\hline $\begin{array}{l}\text { 31. I am afraid that the other students will laugh at me when I } \\
\text { speak the foreign language. }\end{array}$ & 67 & 3.51 & 1.301 \\
\hline $\begin{array}{l}\text { 19. I am afraid that my language teacher is ready to correct every } \\
\text { mistake I make. }\end{array}$ & 67 & 3.65 & 1.307 \\
\hline
\end{tabular}

*Reversed values: The lowest scores represent at all times a high anxiety level.

Table 3. Participants' level of fear of negative evaluation.

Conversely, as far as test anxiety is concerned, philology students appear to show a higher degree of FLA. In fact, these students registered lower mean values in 9 out of 15 items (items 8, 10, 11, 12, 16, 20, 21, 22 and 28) within this category. In spite of this, t-tests showed significant differences between the two groups of students only in 3 items: item 11, '*I don't understand why some people get so upset over foreign language classes' $(\mathrm{t}=$ 2.286; $p=0.026<0.05)$; item $28,{ }^{\prime} *$ When I am on my way to language class, I feel very sure and relaxed' $(\mathrm{t}=-2.340 ; \mathrm{p}=0.022<0.05)$; and item 17 , 'I often feel like not going to my language class' $(\mathrm{t}=2.685 ; \mathrm{p}=0.047<0.009)$. The findings indicate that biology students do not perceive foreign language classes as a potential cause of distress (items 11). They also feel more sure and relaxed than philology students in the English class (item 28) although, interestingly, they admit feeling significantly less motivated to attend the language class (item 17) than philology students.

Finally, with regard to fear of negative evaluation, the descriptive data show more mixed findings, although once again biology students seem to experience a lower degree of anxiety in all the items within this category except for 3 of them (items 2, 13 and 31). Results indicate that biology students are likely to be more concerned about making errors (item 2) and volunteering answers in the language class (item 13) than philology students. They also seem to be more afraid that their classmates will laugh at them when they speak (item 31). However, $\mathrm{t}$-tests only reveal statistically significant differences between group means in item 19: 'I am afraid that my language teacher is ready to correct every mistake I make' $(\mathrm{t}=$ 2.370; $\mathrm{p}=0.021<0.05)$. This finding indicates that biology students are found to experience a significantly lower degree of anxiety about being corrected for their mistakes in front of their fellow classmates than philology students, who seem to be more anxious in this regard. 


\subsection{Are there any differences in the degree of FLA that ESP students experience across gender?}

T-tests were also run to investigate whether there was a significant relationship between gender and each of three types of performance anxiety related to FLA. As regards communication apprehension, descriptive statistics indicate a higher level of anxiety among female students than among their male counterparts in 9 items out of 11 (items 1, 4, 9, 14, 18, 24, 27, 30 and 32). On the contrary, female participants appear not to get so anxious and upset when they do not understand what the teacher is correcting (item 15: $\bar{x}=2.68$ vs. $\bar{x}=$ 2.63), and also feel less restless when they do not understand what the teacher says in the language classroom (item 29: $\bar{x}=2.93$ vs. $\bar{x}=2.92$ ). However, the data show no statistically significant differences between male and female students in terms of communication apprehension.

Likewise, the findings reveal than female students seem to experience a higher degree of anxiety as far as test anxiety is concerned. Thus, females indicate to feel more anxious than males in 11 items (items 3, 8, 10, 12, 16, 20, 21, 22, 25, 26 and 28) out of 15 within this category. Female students only seem to be less anxious than male students when enquired about the possibility of taking more foreign language classes (item $5: \overline{\mathrm{x}}=3.98$ vs. $\overline{\mathrm{x}}=$ 3.89). They also perceive foreign language classes as less distressing (item 11: $\bar{x}=3.08$ vs. $\overline{\mathrm{x}}=3.00$ ), and show a lower tendency to feel like not going to the language class (item 17: $\overline{\mathrm{x}}=3.08$ vs. $\quad \overline{\mathrm{x}}=2.96$ ) or to find themselves thinking of issues not related to the lesson (item $6: \bar{x}=3.05$ vs. $\bar{x}=2.54$ ). However, no statistically significant differences in terms of test anxiety were found as a function of gender.

Similar trends were observed as far as fear of negative evaluation is concerned. In fact, the mean scores of both groups show that female students appear to feel more anxious than male students in all the items within this category with no exception. This finding reveals that, overall, females are likely to be more concerned about the impression others may have of their linguistic competence in the L2 than their male counterparts. Nevertheless, as it occurred in the previous two types of performance anxiety associated with FLA, no statistically significant gender differences were observed in levels of FLA. Therefore, similar to previous research findings (Aida, 1994; Park \& French, 2013), this study reveals that no significant differences between FLA and gender can be established.

\subsection{What is the correlation between foreign language anxiety levels and students' perceptions of their own proficiency?}

Participants were also asked to provide self-ratings of their English proficiency in the four language skills: listening, reading, writing and speaking on a 5-point Likert scale ranging from 1 (excellent) to 5 (very poor). Results indicate that respondents regard their command 
of the English language as rather low, since the mean score of all the skills except for reading registered values over 2.50 on a 5 point-scale: reading $(\bar{x}=2.28)$, writing $(\bar{x}=2.84)$, listening ( $\overline{\mathrm{x}}=2.87$ ), and speaking $(\overline{\mathrm{x}}=3.18)$. As can be observed, respondents ranked speaking as the most critical area followed by listening. In fact, results of the correlation analyses showed strong significant negative correlations at $\mathrm{p}=<0.01$ between the total FLCAS score and participants' perceived level of English proficiency in both skills: listening $(r=-0.622)$ and speaking $(r=-509)$. This means that language anxiety levels seem to increase with participants' self-perceived lack of proficiency in these skills. Therefore, speaking and listening are the skills most clearly affected by FLCA (see Horwitz et al., 1986). These findings also suggest that, in line with previous research (Koul, Roy, Kaewkuekool \& Ploisawaschai, 2009; Liu, 2006; Mak, 2011; Phillips, 1992), the lower the participants' perceived level of English proficiency, the higher the participants' anxiety level. Therefore, FLA may have a negative impact on students' attempts to learn and use the L2.

\section{CONCLUSION}

The results of this study reveal that, similar to other research studies (Arnaiz \& Guillén, 2013, 2012; Liu, 2006), a great majority of ESP students (71.9\%) seem to experience average-to-high levels of anxiety in the English language classroom. This finding suggests that FLA may negatively affect the learning of the English language. Among the different types of performance anxiety, communication apprehension appears to be the major source of students' anxiety, especially as far as speaking anxiety is concerned. Thus, ESP students admit feeling confused, uncomfortable and self-conscious using English in the context of the L2 classroom. In fact, fear of negative evaluation appears to be the second more anxietyprovoking factor related to FLA. Again, participants highlighted aspects related to oral skills as the top anxiety-inducing aspects (see also Aida, 1994; Choi, 2016; Matsuda \& Gobel, 2004) within this category. Thus, they admitted getting nervous when being asked questions they had not prepared in advance or feeling reticent to volunteer answers in the language class due to embarrassment or loss of face. This excessive concern about the academic and personal evaluation of their use of the target language may prevent students from improving their oral communication skills (see Gregersen, 2007; Kim, 2009). The least anxietyprovoking factor related to FLA seems to be test anxiety, although it is worth mentioning that the top highest anxiety-provoking factor across the three main subtypes of performance anxiety was found to be students' worry about the consequences of failing their foreign language class (Salehi \& Marefat, 2014). This result came as no surprise, since obtaining a B2 level before graduation is a degree requirement which might increase students' level of FLA. 
As for students' degree programs, results indicate that there are no statistically significant differences between philology and biology students in terms of communication apprehension. However, significant differences were found between the two groups of students in 3 items related to test anxiety. Thus, biology students appear not to perceive foreign language classes as a potential cause of distress and they feel more sure and relaxed in the English lesson. Interestingly, biology students are also found to be significantly less motivated to attend the language class than philology students. T-tests also revealed statistically significant differences across university degree programs in one item associated with fear of negative evaluation. The data show that biology students seem to experience a significantly lower degree of anxiety about being corrected by their mistakes than philology students, who appear to be more anxious in this respect.

As regards gender, this study supports previous research findings (Aida, 1994; Park \& French, 2013), which observed no statistically significant gender differences in levels of FLA. Therefore, gender does not seem to have an influence on participants' level of FLA.

Finally, correlation analyses reveal strong significant negative correlations between FLA and learners' perceptions of their English proficiency in listening and speaking skills, which suggests that participants' anxiety levels increase as their perceived language proficiency levels in both skills decrease (Koul et al., 2009; Liu, 2006).

Certainly, it would be interesting to examine if further contextual circumstances (such as class methodology, role of the teacher, changes in FLA over the language courses, etc.) may have an influence on the perceived level of students' anxiety in our study, causing anxiety-provoking situations (see Choi, 2016; Kruk, 2018). Likewise, further research on FLA and its association with other variables such as motivation, learning styles, personality, individual differences, as well as with findings in cognitive science (Kormos, 2014) could also yield interesting results since all these aspects seem to be closely interrelated in second language acquisition (SLA) (Park, 2014).

In any event, the results of this study clearly indicate that students suffer a considerable level of anxiety in the L2 classroom mainly associated with oral communication skills (Choi, 2016; Mak, 2011; Park, 2014). Since communicative methodologies have encouraged the promotion of oral skills, it is crucial that we ensure the creation of more supportive instructional environments that may help teachers identify those aspects of the L2 classroom that are more anxiety-inducing (see Al-Saraj, 2014; Ortega-Cebreros, 2003) so that students may overcome FLA and become more successful L2 learners. 


\section{REFERENCES}

Aida, Y. (1994). Examination of Horwitz, Horwitz \& Cope's construct of Foreign Language Anxiety: The case of students of Japanese. The Modern Language Journal, 78(2), 155- 168. doi: 10.1111/j.1540-4781.1994.tb02026.x

Al-Saraj, T. M. (2014). Revisiting the foreign language classroom anxiety scale (FLCAS): The anxiety of female English language learners in Saudi Arabia. L2 Journal, 6, 50- 76.

Amengual-Pizarro, M. (2017). Engineering students' motivational variables towards English and the learning of the English language. Revista para Fines Específicos 23(1), 31- 44. doi: 10.20420/rlfe.2017.156

Arnaiz, P. \& Guillén, F. (2012). Foreign language anxiety in a Spanish university setting: Interpersonal differences. Revista de Psicodidáctica, 17(1), 5- 26.

Arnaiz, P. \& Guillén, F. (2013). Anxiety in Spanish EFL students in different university degree programmes. Anales de Psicología, 29(2), 335-344. doi: 10.6018/analesps.29.2.130791.

Bailey, K. M. (1995). Competitiveness and anxiety in adult second language learning: Looking at and through the diary studies. In H.D. Brown, \& S. T. Gonzo (Eds.), Readings on Second Language Acquisition (pp. 163-205). Englewood Cliffs, NJ: Prentice Hall Regents.

Cheng, Y. S., Horwitz, E. K. \& Shallert, D. L. (1999). Language anxiety: Differentiating writing and speaking components. Language Learning, 49, 417-446. doi:10.1111/0023-8333.00095

Choi, J. (2016). English speaking classroom apprehension: a study of the perception held by Hong Kong university language learners. The Journal of Teaching English for Specific Academic Purpose, 4(2), 293-308. UDC811.111243:37.013(512.317).

Council of Europe (2001). Common European Framework of Reference for Languages: Learning, Teaching, Assessment. Cambridge: Cambridge University Press.

Dörnyei, Z. (2005). The psychology of the language learner: Individual differences in second language acquisition. Mahwah, NJ: Lawrence Erlbaum Associates.

Gregersen, T. G. (2007). Breaking the code of silence: A study of teachers' nonverbal decoding accuracy of foreign language anxiety. Language Teaching Research, 1(2), 209- 221. doi:10.1177/136216880707460

Horwitz, E. K. (1986). Preliminary evidence for the reliability and validity of a foreign language anxiety scale. TESOL Quartely, 20, 559- 562. doi:10.2307/3586302

Horwitz, E. K. (2001). Language anxiety and achievement. Annual Review of Applied Linguistics, 21, 112- 126. doi:10.1017/S0267190501000071

Horwitz, E. K., Howitz, M. B. \& Cope, J. (1986). Foreign language classroom anxiety. Modern Language Journal, 70, 125- 132.

Horwitz, E. K. \& Young, D. J. (Eds.). (1991). Language Anxiety: From theory and practice to classroom implications. Englewood Cliffs, NJ: Prentice-Hall.

Kim, S. Y. (2009). Questioning the stability of foreign language classroom anxiety and motivation across different classroom contexts. Foreign Language Annals, 42(1), 138- 157. doi:10.1111/j.1944-9720.2009.01012.x

Koul, R., Roy, L., Kaewkuekool, S. \& Ploisawaschai, S. (2009). Multiple goal orientations and foreign language anxiety. System, 37, 676- 688. doi:10.1016/j.system.2009.09.011 
Kormos, J. (2014). Speech production and second language acquisition. New York, NY \& London: Routledge.

Krashen, S. D. (1985). The input hypothesis: Issues and implications. New York, NY: Longman.

Kru, M. (2018). Changes in foreign language anxiety: A classroom perspective. International Journal of Applied Linguistics, 28, 31-57

Liu, H. J. (2013). Effects of Foreign Language Anxiety and Perceived Competence on Learning Strategy Use. International Journal of English Linguistics, 3(3), 76- 87. doi:10.5539/ijel.v3n3p76

Liu, M. (2006). Anxiety in Chinese EFL students at different proficiency levels. System, 34(3), 301316. doi:10.1016/j.system.2006.04.004.

MacIntyre, P. D. (1999). Language anxiety: A review of the research for language teachers. In D. J. Young (Ed.), Affect in foreign language and second language learning: A practical guide to creating a low-anxiety classroom atmosphere (pp. 24-45). Boston, MA: McGraw-Hill.

MacIntyre, P. D. \& Gardner, R. (1991). Methods and results in the study of anxiety and language learning: A review of literature. Language Learning, 41, 85- 117. doi:10.1111/j.14671770.1991.tb00677.x

MacIntyre, P. D. \& Gardner, R. (1994). The subtle effects of language anxiety on cognitive processing in the second language. Language Learning, 44, 283- 305. doi: 10.1111/j.14671770.1994.tb01103.x

Mak, B. (2011). An exploration of speaking-in-class anxiety with Chinese ESL learners. System, 39(2), 202-214. doi:10.1016/j.system.2011.04.002.

Matsuda, S. \& Gobel, P. (2004). Anxiety and predictors of performance in the foreign language classroom. System, 32(1), 21- 36. doi: 10.1016/j.system.2003.08.002 22

Park, G. P. (2014) Factor Analysis of the Foreign Language Classroom Anxiety Scale in Korean Learners of English as a Foreign Language. Psychological Reports, 115(1), 261-275. doi: 10.2466/28.11.PR0.115c10z2

Park, G. P \& French, B. F. (2013). Gender differences in the Foreign Language Classroom Anxiety Scale. System, 41(2), 462-471. doi: 10.1016/j.system.2013.04.001

Pavlenko, A. (Ed.). (2011). Thinking and speaking in two languages. Clevdon: Multilingual Matters.

Pellegrino-Aveni, V. A. (2005). Study abroad and second language use: Constructing the self. Cambridge: Cambridge University Press.

Pérez-Paredes, P. \& Martínez-Sánchez, F. (2001). A Spanish version of the foreign language classroom anxiety scale: Revisiting Aida's factor analysis. Revista Española de Lingüística Aplicada RESLA, 14, 337-352.

Phillips, E. M. (1992). The effects of language anxiety on students' oral test performance and attitudes. Modern Language Journal, 76, 14-26. doi: 10.2307/329894

Onwuegbuzie, A. J., Bailey, P. \& Daley, C. E. (2000). Cognitive, affective, personality, and demographic predictors of foreign-language achievement. The Journal of Educational Research, 94, 3- 15. doi: 10.1080/00220670009598738

Ortega-Cebreros, A. (2003). Measuring language anxiety perceived by Spanish university students of English. Bells: Barcelona English language and literature studies, 12. Retrieved from http://www.raco.cat/index.php/bells/article/viewArticle/82928/0/

(C) Servicio de Publicaciones. Universidad de Murcia. All rights reserved. IJES, vol. 18(2), 2018, pp. 145-159 Print ISSN: 1578-7044; Online ISSN: 1989-6131 
Rodríguez, M. \& Abreu, O. (2003). The stability of general foreign language classroom anxiety across English and French. The Modern Language Journal, 87(3), 365-374.

Salehi, M. \& Marefat, F. (2014). The effects of foreign language anxiety and test anxiety on foreign language test performance. Theory and practice in language studies, 4(5), 931-940. doi:10.4304/tpls.4.5.931-940

Schumann, J.H. (1978). The Pidginization process: A model for second language acquisition. Rowley, MA: Newbury House.

Spielman, G. \& Radnofsky, M. (2001). Learning language under tension: New directions from a qualitative study. The Modern Language Journal, 85, 259-278.doi: 10.1111/0026-7902.00108

Yang, H. C. (2012). Language Anxiety: From the classroom to the community. English Teaching and Learning, 36 (4), 1-28. doi: 10.633./ETL.2012.36.4.01.

Young, D. J. (1991). Creating a low-anxiety classroom environment: What does language anxiety research suggest? The Modern Language Journal, 5, 426- 437. doi: 10.2307/329492

Young, D. J. (1992). Language anxiety from the foreign language specialist's perspective: Interviews with Krashen, Omaggio Hadley, Terrell, and Rardin. Foreign Language Annals, 19, 439- 445. doi: 10.1111/j.1944-9720.1992.tb00524.x

Williams, K. E. \& Andrade, M. R. (2008). Foreign language learning anxiety in Japanese EFL university classes: Causes, coping, and locus of control. Foreign Language Teaching, 5(2), $181-191$.

Woodrow, L. (2006). Anxiety and speaking English as a second language. RELC Journal, 37(3), 308328. doi:10.1177/0033688206071315. 